\title{
Petrology and Geochemistry of Dikes in the North of Saveh in Iran
}

\author{
Mohammad-Hassan Bazoobandi1, Mohammad-Ali Arian ${ }^{1 *}$, Mohammad-Hashem Emami², \\ Gholamreza Tajbakhsh ${ }^{3}$, Abdollah Yazdi ${ }^{4}$ \\ ${ }^{1}$ Department of Geology, Faculty of Science, North Tehran Branch, Islamic Azad University, Tehran, Iran \\ ${ }^{2}$ Department of Geology, Faculty of Science, Islamshahr Branch, Islamic Azad University, Tehran, Iran \\ ${ }^{3}$ Department of Geology, Faculty of Science, Yazd University, Yazd, Iran \\ ${ }^{4}$ Department of Geology, Faculty of Science, Kahnooj Branch, Islamic Azad University, Kerman, Iran \\ Email: *maa1361@yahoo.com
}

Received 20 December 2015; accepted 6 March 2016; published 9 March 2016

Copyright (C) 2016 by authors and Scientific Research Publishing Inc.

This work is licensed under the Creative Commons Attribution International License (CC BY).

http://creativecommons.org/licenses/by/4.0/

c) (i) Open Access

\section{Abstract}

Dikes in the north of Saveh are located in a region with an area of approximately 200 square kilometers, in a distance of approximately 100 kilometers south of Tehran. Dikes mentioned in terms of petrological composition, are divided into two categories: alkaline and intermediate to acidic. Alkaline dikes include: andesitic basalt and andesite and intermediate to acidic dikes include: trachyte and trachyandesite. In terms of geochemical, dikes in the north of Saveh have a dual nature of alkaline and calc-alkaline. Both groups are derived from more enrichment source than primitive mantle. Despite similarity of pattern of both groups, varieties of alkaline having less silica, in the elements $\mathrm{Sr}, \mathrm{Ti}, \mathrm{Nb}$ and $\mathrm{Ta}$ show more enrichment and in the elements $\mathrm{Hf}, \mathrm{Rb}, \mathrm{Th}, \mathrm{K}$ show less enrichment than varieties of calc-alkaline.

\section{Keywords}

Swarm Dikes, Alkaline and Calc-Alkaline, Saveh, Iran

\section{Introduction}

The studied area with an area of approximately 200 square kilometers, in the north of Saveh city, is located between $55^{\circ} 15^{\prime}$ to $55^{\circ} 50^{\prime}$ East and $35^{\circ} 00^{\prime}$ to $35^{\circ} 15^{\prime}$ North. In this area, more than 250 dikes with an approximate thickness of 0.4 to $12 \mathrm{~m}$ and a length of approximately 50 to 3000 meters have been intruded in an area of approximately 200 square kilometers and with a combination of andesitic basalt, andesite and trachyte in Eocene

\footnotetext{
${ }^{*}$ Corresponding author.
}

How to cite this paper: Bazoobandi, M.-H., Arian, M.-A., Emami, M.-H., Tajbakhsh, G. and Yazdi, A. (2016) Petrology and Geochemistry of Dikes in the North of Saveh in Iran. Open Journal of Marine Science, 6, 210-222.

http://dx.doi.org/10.4236/ojms.2016.62017 
volcanic rocks (Figure 1). Studied swarm dikes, are alike type IV swarm dikes of Ernst [1] which are due to creation of the regional stress fields [4]. According to the studies of Hou [2] and [3], dikes in this area can be considered similar to dikes parallel to the linear pattern which have created in a relatively wide area and influenced by regional tensions caused by a phenomenon such as subduction [4].

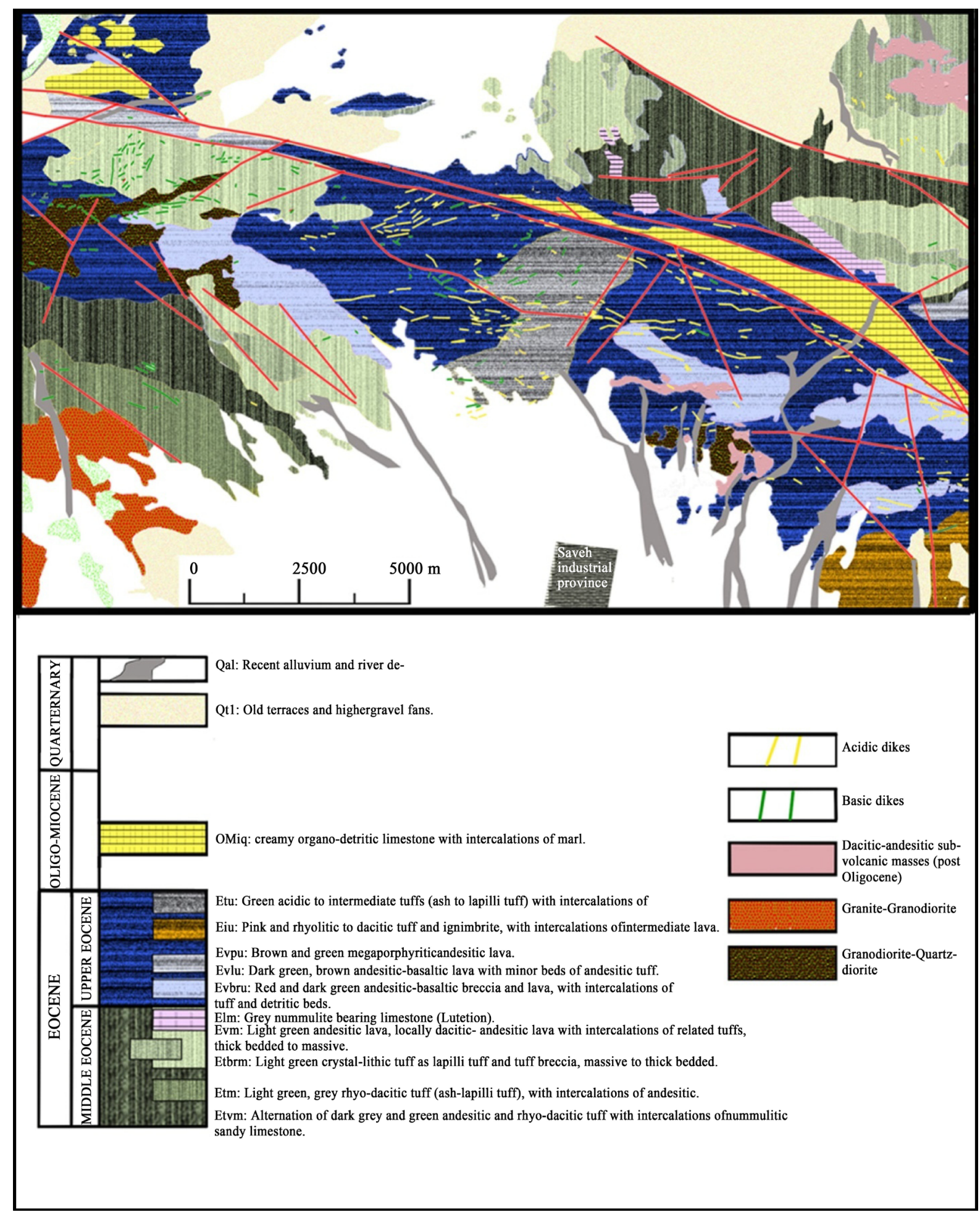

Figure 1. Dikes in the north of Saveh on the geological map of the studied area [4]. 
Previous studies in this area have been carried out by different people and Geological Survey of Iran, in the form of preparing geological mapping at a scale of 1:100,000 and 1:250,000. Based on the studies, the mentioned dikes are acidic and alkaline dikes [5] and have the feeder role of Eocene volcanic rocks of the region [4]. In this article it is tried to introduce a variety of petrology, geochemical characteristics and tectonomagmatic environment of dikes in the north of Saveh. In this regard, after doing field studies and detailed petrography, 15 samples of dikes have been subjected to chemical analysis by XRF ICP_MAS and methods in laboratories of the University of Tarbiat Modarres and Zarazma Company for major, minor and trace elements (Table 1), then on two selected samples, 44 point microprobe analyses were carried out by electron microprobe machine type GEOL8200 in the laboratory of the University of Lisbon in Portugal to determine the mineral types (Table 2 and Table 3).

\section{Geology of the Area}

In the division of geological units, the studied area is a part of the volcanic zone of Orumieh-Dokhtar. The most ancient rocks in this area is dependent on the Middle Eocene. In general, structures in this area have a trend of the West-North West, East-South East. The most important structural elements in this area are original fractures and folding. Due to governing movement pattern of the area (shear-compressional) in most cases, regional faults zone have both horizontal and vertical displacement components [6]. Swarm dikes investigated in this study, are cut Tertiary volcanic rocks (Figure 2).

\section{Petrography}

Dikes in the studied area are generally divided into two categories: alkaline and intermediate to acidic.

\subsection{Alkaline Dikes}

These dikes in terms of petrology include andesitic basalt, basaltic andesite and andesite. Their texture is Porphyritic, Hyalo porphyritic with microlitic pulp and sometimes glomeroporphyritic. Plagioclase Phenocrysts with a combination of Andesine (An\% = 42.59) to labradorite (An\% = 50.73) semi-shaped to self-shaped make their coarsely crystals (Figure 3(a) and Figure 3(b)). Some of them are quite normal and have zoning (An\% = 47.77 - 50.5) (Figure 3(c)) with inclusions of biotite. Plagioclase strongly altered and changed to sericite.

Pyroxenes are in the form of semi-shaped Phenocrysts of augite type with chemical changes of En43.45 Fs15.37Wo41.43 to En40.06Fs23.51Wo36.43 (Figure 4) which partly are altered to chlorite and amphibole. In glomeroporphyritic sectors, pyroxene phenocrysts are often as integrated crystals with each other and completely altered so that only their shape remains and their empty space is filled with calcite and quartz and opaque minerals. Just in a few spots small parts of them remain.

Another mafic mineral in these rocks, is olivine in very low quantity which is completely altered and their vacancies are filled by epidote and calcite and remain only spherical forms of them in size about one millimeter. These minerals are often in a basis of composed plagioclase microlites and fine opaque minerals and scattered and a little glass with an eligible spherical cavities in the size of $\mathrm{mm}$ and are filled by radial calcite and iron oxides.

\subsection{Intermediate to Acidic Dikes}

Intermediate to acidic dikes are included Trachyte and trachyandesite. Trachytic dikes of the area show trachytic, microlitic and glomeroporphyritic texture. Phenocrysts in some trachytic cases are very rare. These phenocrysts are types of self-shaped sanidine and have 500 microns dimension. Other phenocrysts samples are pyroxene and plagioclase (Figure 5). Almost all phenocrysts completely altered and only original form of these phenocrysts is remaining. Background of these rocks entirely consists of oriented microlites of feldspar which along with them secondary fine crystal biotites are seen. These biotites are result of recrystallization of primary biotites. Finegrained opaque and amorphous minerals are scattered in the total amount of rocks and their quantity is less than $5 \%$. Sericites are scattered and can be seen in the context as fine crystals. Calcite and hematite are scattered in the whole context of stone and in pores sized in $\mathrm{mm}$ also calcite and hematite is formed with opaque minerals.

\section{Geochemistry}

In the diagram $\mathrm{Na}_{2} \mathrm{O}+\mathrm{K}_{2} \mathrm{O}-\mathrm{SiO}_{2}$ [7] the composition of dikes samples are in two sub-alkaline and alkaline 


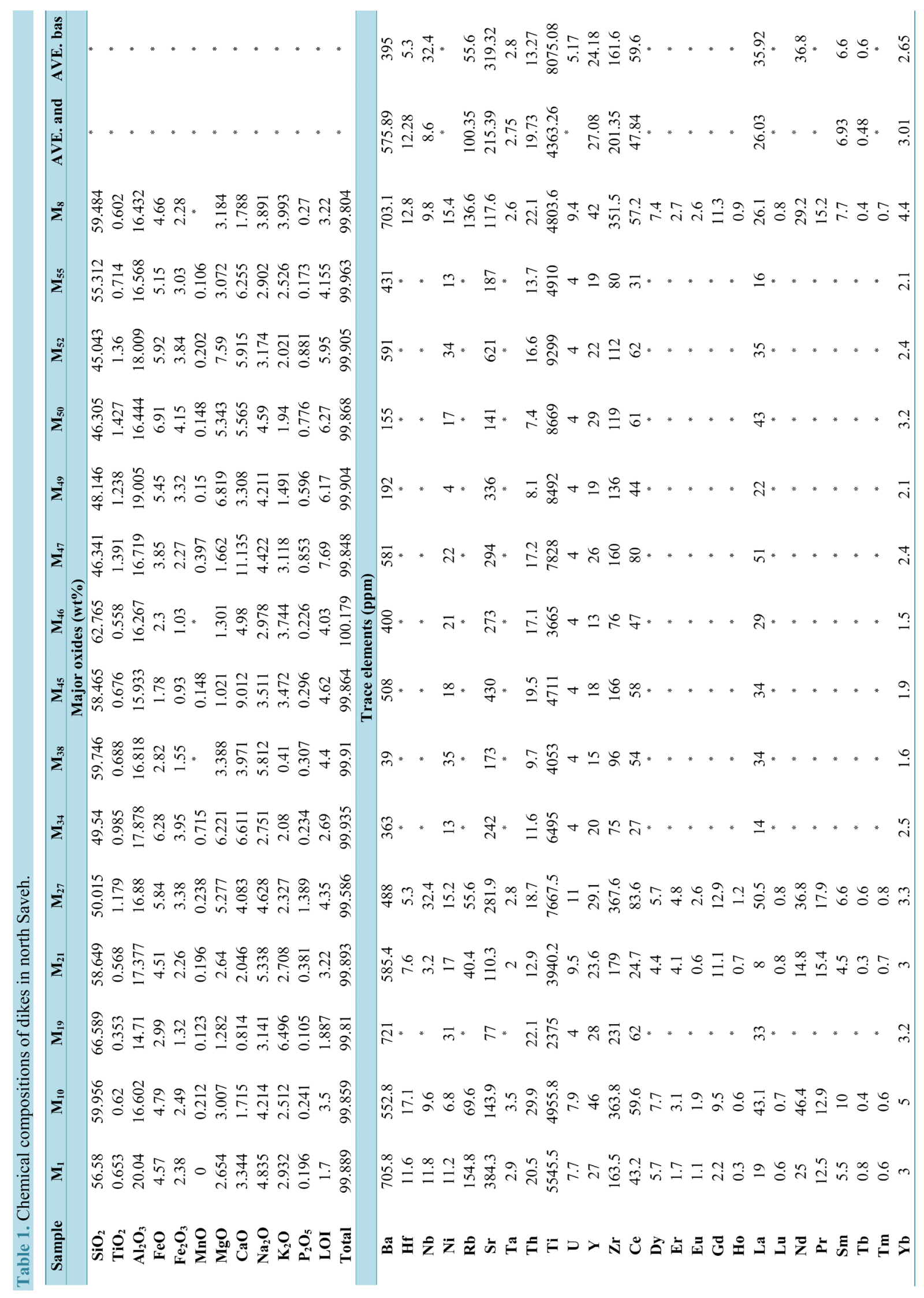




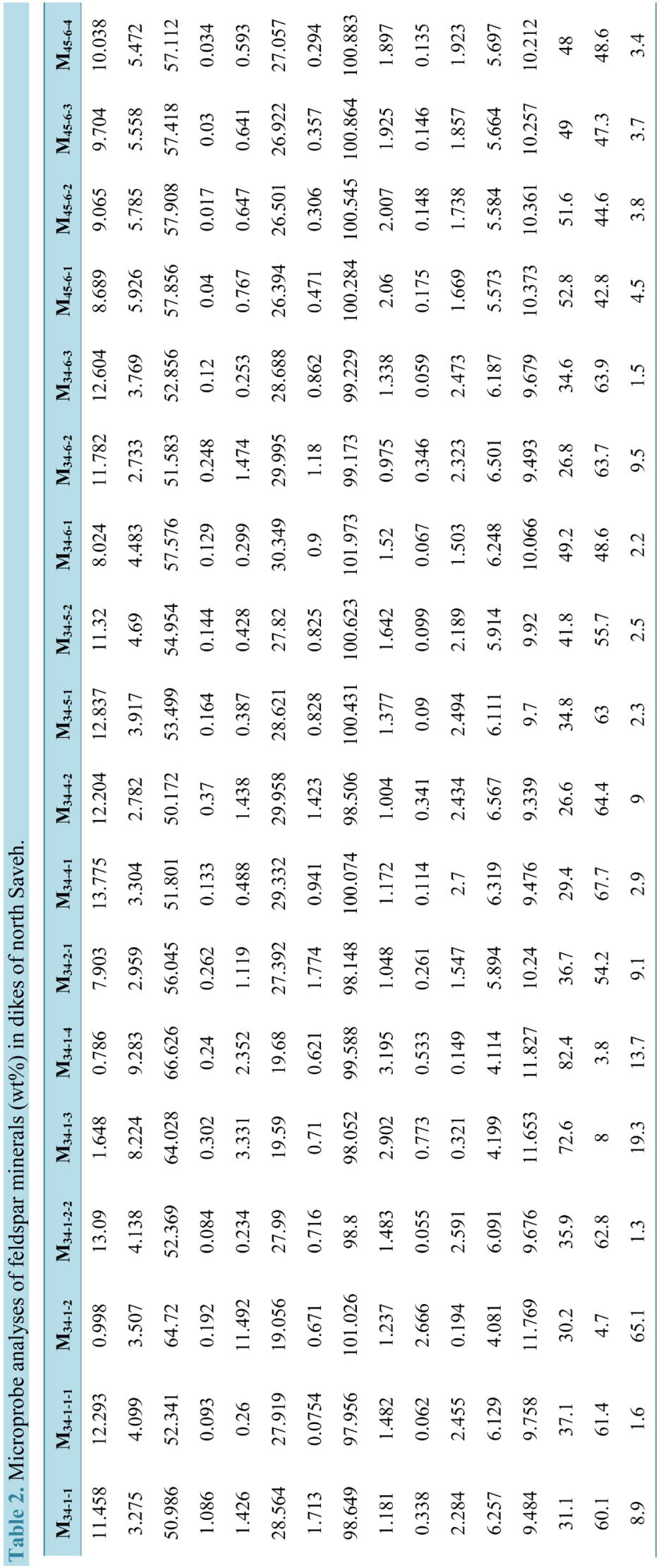


Table 3. Microprob analyses of pyroxen minerals (wt\%) in dikes of north Saveh.

\begin{tabular}{|c|c|c|c|c|c|c|c|}
\hline Sample & $\mathbf{M}_{45-1-1}$ & $\mathbf{M}_{45-1-2}$ & $\mathbf{M}_{34-1-1}$ & $\mathbf{M}_{34-2-2}$ & $\mathbf{M}_{34-4-2}$ & $\mathbf{M}_{34-5-2}$ & $\mathbf{M}_{34-7-2}$ \\
\hline $\mathrm{CaO}$ & 21.224 & 21.703 & 18.693 & 18.347 & 18.526 & 18.304 & 17.371 \\
\hline $\mathrm{SiO}_{2}$ & 52.429 & 52.198 & 51.093 & 50.772 & 51.115 & 51.719 & 50.49 \\
\hline $\mathrm{Cr}_{2} \mathrm{O}_{3}$ & 0.0103 & 0.029 & 0.088 & 0.086 & 0.07 & 0.086 & 0.062 \\
\hline $\mathrm{Na}_{2} \mathrm{O}$ & 0.377 & 0.32 & 0.257 & 0.27 & 0.267 & 0.275 & 0.291 \\
\hline $\mathrm{TiO}_{2}$ & 0.348 & 0.262 & 0.597 & 0.585 & 0.588 & 0.551 & 0.753 \\
\hline MnO & 0.402 & 0.436 & 0.341 & 0.331 & 0.402 & 0.358 & 0.427 \\
\hline MgO & 13.944 & 14.114 & 15.185 & 14.951 & 14.811 & 15.021 & 13.728 \\
\hline $\mathrm{ZnO}$ & 0.067 & 0.008 & 0.074 & 0 & 0 & 0.055 & 0.002 \\
\hline FeO & 10.12 & 10.107 & 10.628 & 11.292 & 11.775 & 11.064 & 13.929 \\
\hline $\mathbf{A l}_{2} \mathbf{O}_{3}$ & 1.216 & 1.086 & 2.49 & 2.501 & 1.963 & 2.17 & 2.571 \\
\hline $\mathbf{K}_{2} \mathbf{O}$ & 0.011 & 0 & 0 & 0 & 0 & 0.003 & 0 \\
\hline Tota & 100.241 & 100.36 & 99.457 & 99.21 & 99.58 & 99.736 & 99.728 \\
\hline TSi & 1.956 & 1.943 & 1.912 & 1.908 & 1.919 & 1.936 & 1.909 \\
\hline TAl & 0.044 & 0.048 & 0.088 & 0.092 & 0.081 & 0.064 & 0.091 \\
\hline $\mathbf{T F e}_{3}$ & 0 & 0 & 0 & 0 & 0 & 0 & 0 \\
\hline $\mathbf{M}_{1} \mathrm{Al}$ & 0.01 & 0 & 0.022 & 0.019 & 0.006 & 0.032 & 0.024 \\
\hline $\mathbf{M}_{1} \mathbf{T i}$ & 0.01 & 0.007 & 0.017 & 0.017 & 0.017 & 0.016 & 0.021 \\
\hline $\mathbf{M}_{1} \mathrm{Fe}_{3}$ & 0 & 0 & 0 & 0 & 0 & 0 & 0 \\
\hline $\mathbf{M}_{1} \mathrm{Fe}_{2}$ & 0.205 & 0.208 & 0.112 & 0.124 & 0.147 & 0.112 & 0.179 \\
\hline $\mathrm{M}_{1} \mathrm{Cr}$ & 0 & 0.001 & 0.003 & 0.003 & 0.002 & 0.003 & 0.002 \\
\hline $\mathbf{M}_{1} \mathbf{M g}$ & 0.776 & 0.783 & 0.847 & 0.838 & 0.829 & 0.838 & 0.774 \\
\hline $\mathrm{M}_{1} \mathrm{Ni}$ & 0 & 0.001 & 0 & 0.001 & 0 & 0 & 0 \\
\hline $\mathbf{M}_{2} \mathbf{M g}$ & 0 & 0 & 0 & 0 & 0 & 0 & 0 \\
\hline $\mathbf{M}_{2} \mathrm{Fe}_{2}$ & 0.111 & 0.107 & 0.221 & 0.231 & 0.223 & 0.234 & 0.261 \\
\hline $\mathbf{M}_{2} \mathbf{M n}$ & 0.013 & 0.014 & 0.011 & 0.011 & 0.013 & 0.011 & 0.014 \\
\hline $\mathrm{M}_{2} \mathrm{Ca}$ & 0.848 & 0.866 & 0.75 & 0.739 & 0.745 & 0.734 & 0.704 \\
\hline $\mathrm{M}_{2} \mathrm{Na}$ & 0.027 & 0.023 & 0.019 & 0.02 & 0.019 & 0.02 & 0.021 \\
\hline $\mathbf{M}_{2} \mathbf{K}$ & 0.001 & 0 & 0 & 0 & 0 & 0 & 0 \\
\hline Sum_cat & 3.999 & 4 & 4 & 4 & 4 & 4 & 4 \\
\hline XCa & 0.97 & 0.97 & 0.98 & 0.97 & 0.98 & 0.97 & 0.97 \\
\hline XMg & 0.7 & 0.7 & 0.71 & 0.7 & 0.68 & 0.7 & 0.63 \\
\hline Ca & 43.454 & 43.778 & 38.633 & 38.044 & 38.086 & 38.036 & 36.431 \\
\hline Mg & 39.723 & 39.613 & 43.666 & 43.136 & 42.366 & 43.43 & 40.059 \\
\hline $\mathbf{F e}_{2}-\mathbf{M n}$ & 16.823 & 16.609 & 17.702 & 18.819 & 19.548 & 18.534 & 23.51 \\
\hline JD1 & 0.488 & 0 & 0.957 & 0.961 & 0.282 & 1.037 & 1.1 \\
\hline AE1 & 0.924 & 1.163 & 0 & 0.048 & 0.708 & 0 & 0 \\
\hline CFTS1 & 0 & 0 & 0.134 & 0.083 & 0 & 0.131 & 0.095 \\
\hline CTTS1 & 0.496 & 0.369 & 0.863 & 0.848 & 0.846 & 0.8 & 1.104 \\
\hline CATS1 & 0 & 0 & 0.163 & 0 & 0 & 0.592 & 0.119 \\
\hline WO1 & 42.624 & 43.203 & 37.318 & 36.935 & 37.111 & 36.341 & 34.968 \\
\hline EN1 & 39.418 & 39.427 & 43.49 & 42.934 & 42.222 & 43.234 & 39.901 \\
\hline FS1 & 16.049 & 15.838 & 17.076 & 18.191 & 18.831 & 17.865 & 22.712 \\
\hline $\mathbf{Q}$ & 1.94 & 1.963 & 1.929 & 1.931 & 1.944 & 1.919 & 1.918 \\
\hline $\mathbf{J}$ & 0.055 & 0.046 & 0.037 & 0.039 & 0.039 & 0.04 & 0.043 \\
\hline WO & 43.454 & 43.778 & 38.633 & 38.044 & 38.086 & 38.036 & 36.431 \\
\hline EN & 39.723 & 39.613 & 43.666 & 43.136 & 42.366 & 43.43 & 40.059 \\
\hline FS & 16.823 & 16.609 & 17.702 & 18.819 & 19.548 & 18.534 & 23.51 \\
\hline WEF & 97.282 & 97.717 & 98.114 & 98.014 & 98.052 & 97.974 & 97.839 \\
\hline JD & 2.718 & 0 & 1.886 & 1.986 & 1.948 & 2.026 & 2.161 \\
\hline AE & 0 & 0.023 & 0 & 0 & 0 & 0 & 0 \\
\hline
\end{tabular}




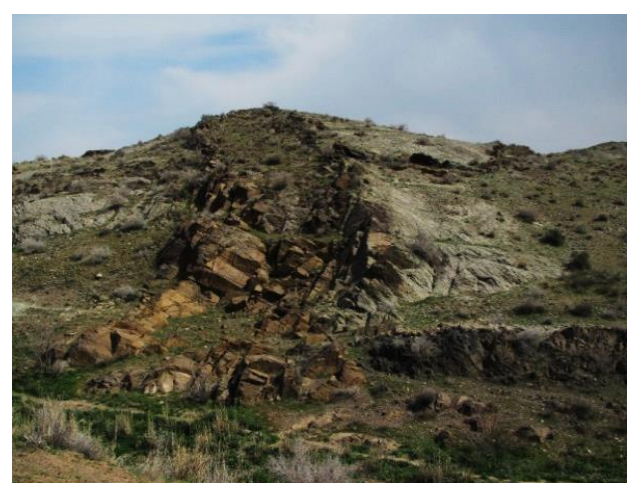

(a)

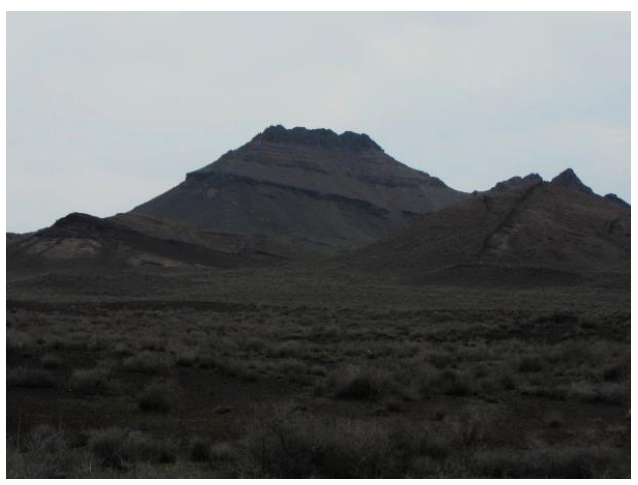

(b)

Figure 2. (a) Intermediate dike; (b) Penetration of dikes in the upper eocene pyroclastic units.

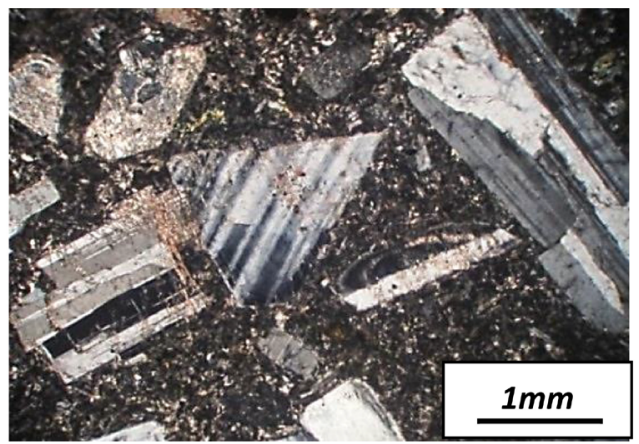

(a)

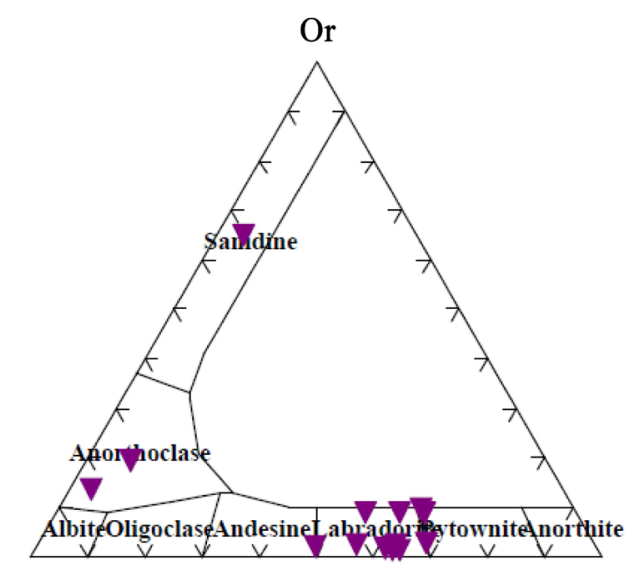

$\mathrm{Ab}$

(b)

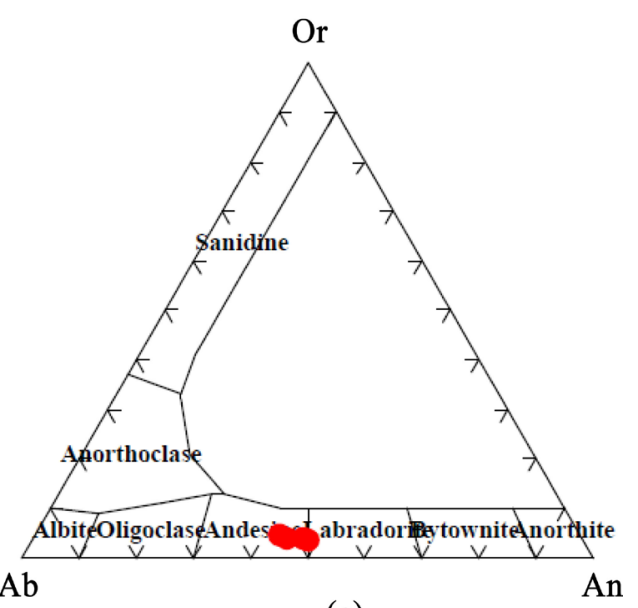

(c)

Figure 3. (a) Plagioclase phenocrysts in basic dikes; (b) The mineralogical composition of andesitic basalt feldspars (sample $M_{34}$ ) based on microprobe analysis; (c) Changes in mineralogical composition zoned feldspar structure $M_{45-6-1}$ to $M_{45-6-4}$.

sectors. Dikes with high silica have calc-alkaline nature and more basic samples have alkaline nature (Figure 6(b)). Also this duality is well observed in the diagram of Cox [8] (Figure 6(a)). Basic samples have petrology composition of alkaline basalt and hawaiite, and dikes more enriched by silica have trachyandesite and rhyolite composition.

By examining variation diagrams of main elements' oxides versus $\mathrm{SiO}_{2}$ (Figure 7), at first, a discontinuity in the value of silica of 46 to 55 is observed. This dual role does not prevent the regular changes of various oxides. So that from variation diagrams of $\mathrm{FeO}$ and $\mathrm{MgO}$ versus $\mathrm{SiO}_{2}$, generally show an obvious reduction trend with development process of subtraction. Reducing these elements suggests the idea of their participation in the 
structure of ferromagnesian minerals such as olivine, hornblende and biotite and titanium oxide during magma differentiation.

However, distribution of points in the $\mathrm{CaO}$ diagram, which probably due to propylitic alteration in some samples, a decreasing trend can be seen in the collections of basic and intermediate-acidic, this decline may be due to their participation in the structure of plagioclase and pyroxene. $\mathrm{Al}_{2} \mathrm{O}_{3}$ content of the samples is relatively fixed with the progress of differentiation in two types of stones, but shows an overall downward trend for it. Reducing this oxide indicates its consumption to make a variety of silicates.

In the changing $\mathrm{Na}_{2} \mathrm{O}$ graph there is no specific process. This element in the structure of minerals that are firstly crystallized is not used and with differentiation progress, its increased amount in the melt has been

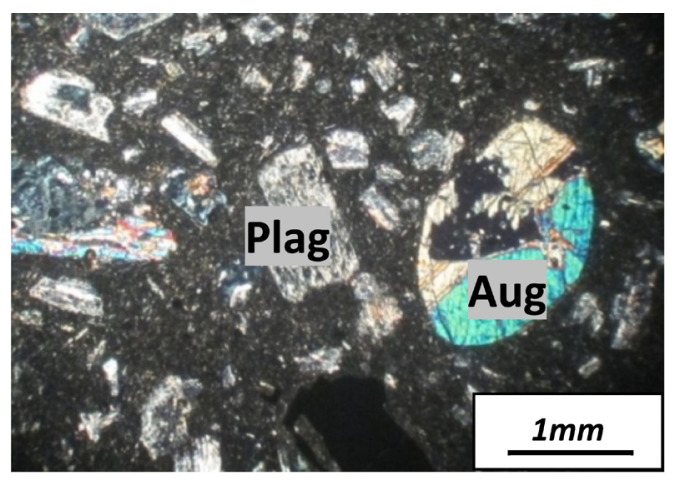

(a)
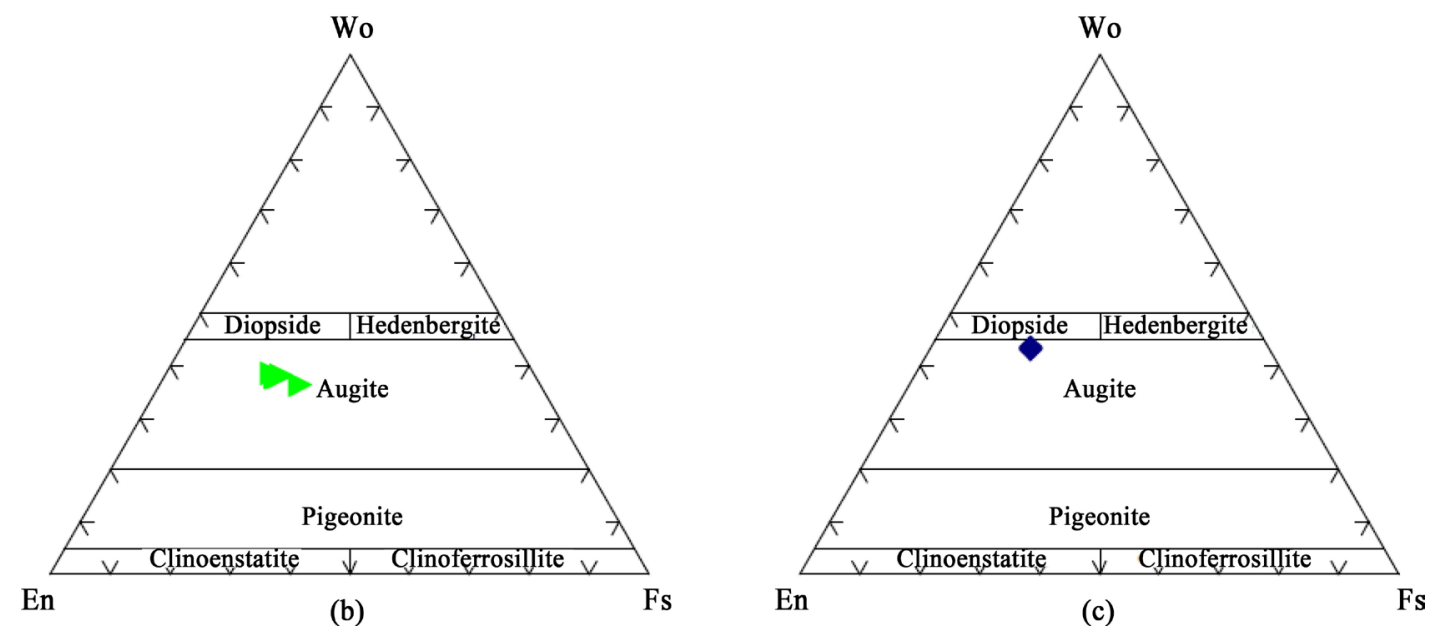

Figure 4. (a) Augite mineral with plagioclase (XPL); (b) Chemical composition of pyroxene in andesitic basalt based on microprobe analysis; (c) Type of pyroxenes in andesitic dikes (sample $\mathrm{M}_{45}$ ) based on microprobe analysis.

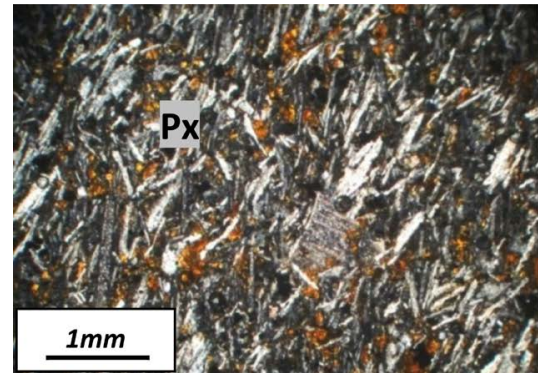

(a)

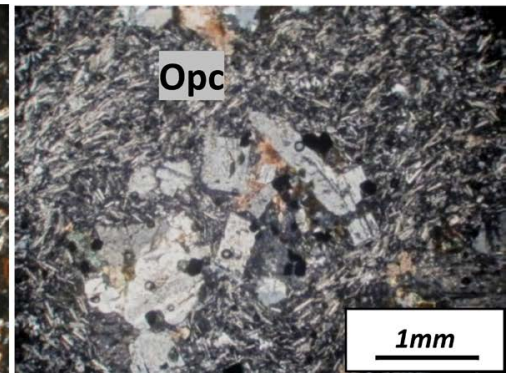

(b)

Figure 5. (a) Trachyte texture and general view of rock, magnification; (b) Glomeruporphyritic texture composed of feldspar, mafic and opaque minerals. 

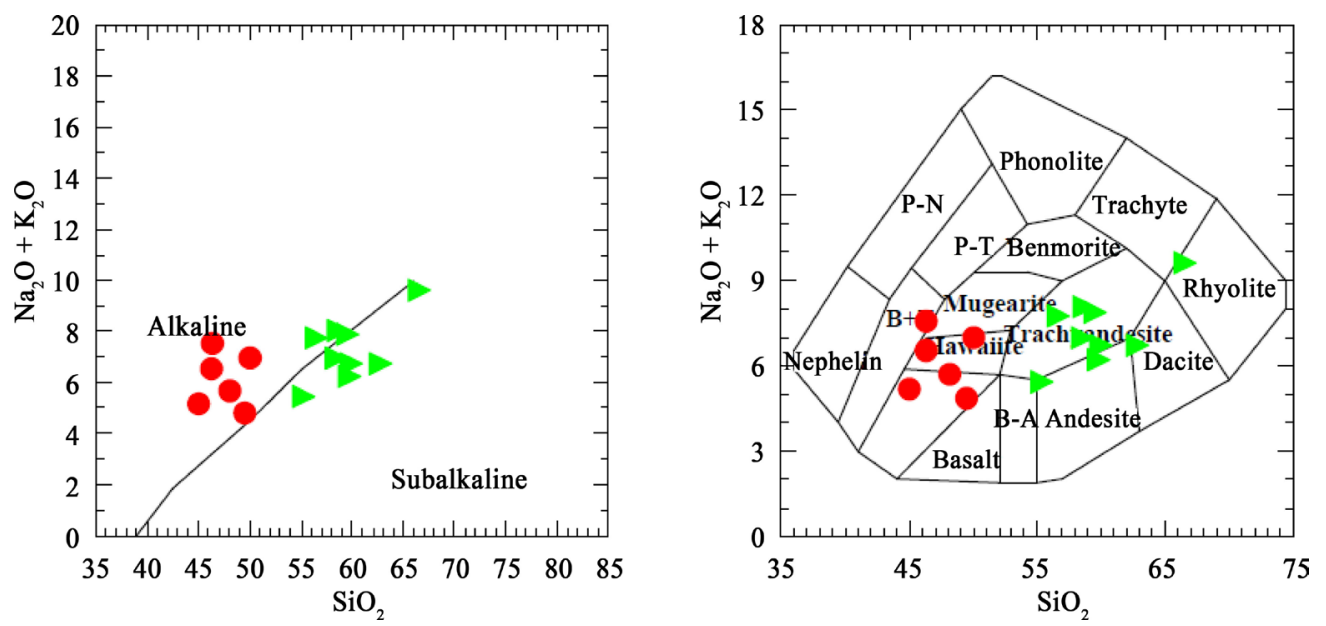

Figure 6. (a) and (b) The geochemical nature of dikes in the north of Saveh.
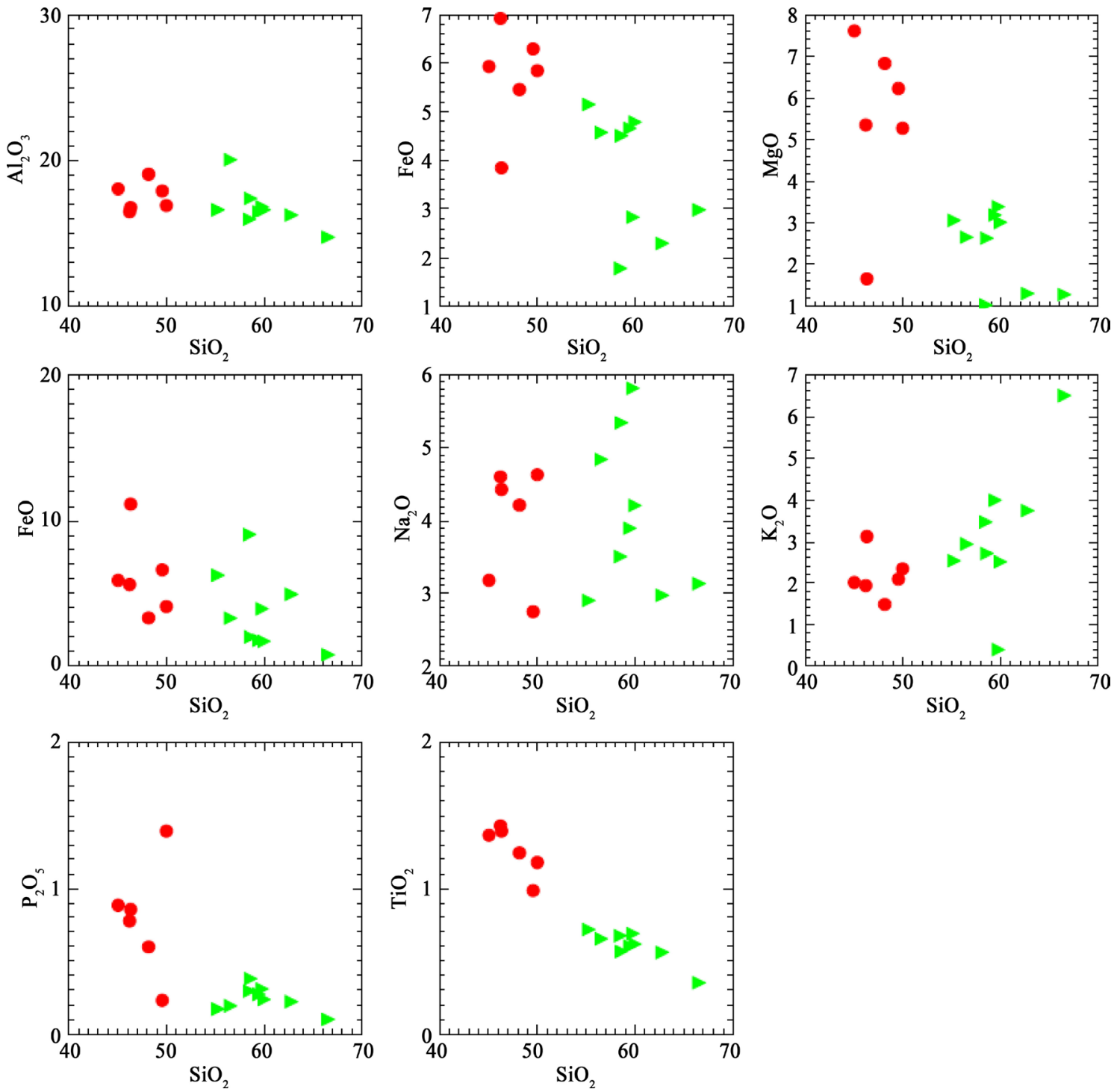

Figure 7. Variation diagrams of the main elements oxides versus $\mathrm{SiO}_{2}$. 
increased and finally inters into the feldspar structure. Rising trend of $\mathrm{K}_{2} \mathrm{O}$ showed that with progress of differentiation its value in the melt increases and fractional and eventually enter the structure of feldspar.

In general, in most variation diagrams, dispersions are observed that may be a sign of digestive processes that affect the differentiation process. Irregular distribution of sodium, potassium and calcium plots and decreasing amounts of iron, phosphorus, calcium and aluminum may be a sign of digestion or react with the rocks in the path that have had high content of elements above.

Spider diagrams: examining normalized plot [9], the average of both dikes, compared to primitive mantle, following results are obtained (Figure 8):

- Both groups compared to primitive mantle are originated from more enriched source. This enrichment in LILE elements such as $\mathrm{Rb}$, Th, $\mathrm{U}$ and $\mathrm{K}$ is higher.

- Despite pattern similarities between two groups, alkaline types which have less silica, in elements $\mathrm{Sr}, \mathrm{Ti}, \mathrm{Nb}$ and Ta have more enrichment and in elements $\mathrm{Hf}, \mathrm{Rb}, \mathrm{Th}, \mathrm{K}$ have less enrichment than the calc-alkaline.

- Abundant elements in oceanic island basalts than the crust such as Re and La in alkaline types are more abundant.

\section{Discussion}

In geochemical investigation of samples of dikes in the north of Saveh it is clear that they have a dual nature of alkaline and calc-alkaline. From the view point of Pearce [10] evaluating the ratio of highly incompatible elements, per less incompatible, such as $\mathrm{Zr}$ and $\mathrm{Th}$ (shell maker) and $\mathrm{Nb}$ and $\mathrm{Ta}$ (mantle maker) to $\mathrm{Y}$ and $\mathrm{Yb}$ (i.e. mantle arrangement diagram) is a very useful method to understand the way of metasomatism and other processes role in the magma genesis and different enrichments. According to [11] and [12], abundance of elements with high stability such as Ta and $\mathrm{Nb}$ than light earth elements in the lithospheric mantle is low, so ratios more than one in $\mathrm{Nb} / \mathrm{La}$ is a sign of asthenosphere mantle source like OIB and less than 0.5 is a sign of lithospheric mantle source. In diagram of (Figure 9(a)) used by [13], most samples are in lithosphere sector.

Pearce [10] indicates that the most useful charts to explore the role and involvement of mantle or subduction components, is chart $\mathrm{Th} / \mathrm{Yb}-\mathrm{Ta} / \mathrm{Yb}$, because Th is a sensitive index for subduction constructive interference and $\mathrm{Ta}$ is related to asthenospheric mantle constructive (in-plane) [10]. Incompatible element $\mathrm{Yb}$ (which is non-moving in subduction), only changes during partial melting process in the presence of remaining Garnett. Being rich or empty of magma source, is determined by high or low proportion of the $\mathrm{Ta} / \mathrm{Yb}$ and adding subduction melt with high ratio of $\mathrm{Th} / \mathrm{Yb}$ [14] and [15]. The position of the studied samples shows enriched origin influenced by the subducted material with fractionation process (Figure 9(b)). According to El-Bialy [16] placement of the samples in parallel arrangement of the mantle, is a sign of mantle enriched by the rim, AFC process or both.

On the other hand, consecutive exposure of a variety of calc-alkaline enriched by potassium and alkaline adjacent to each other, have characteristics of post-collision areas [17]-[19]. These features, along with enrichment LREE and FREE with LIEL and depletion of HREE and HFSE, can be a sign of magmas after the collision, and

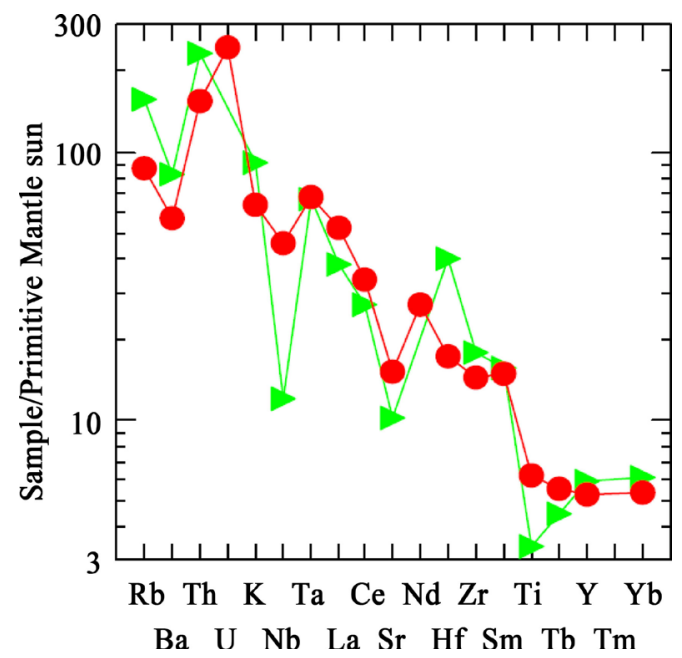

Figure 8. Patterns of normalized rare elements to primitive mantle in two groups of dikes in Saveh. 


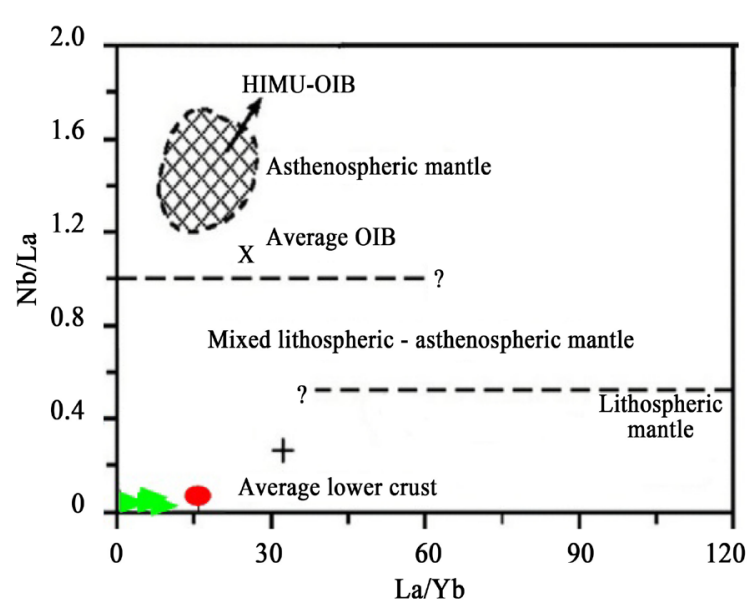

(a)

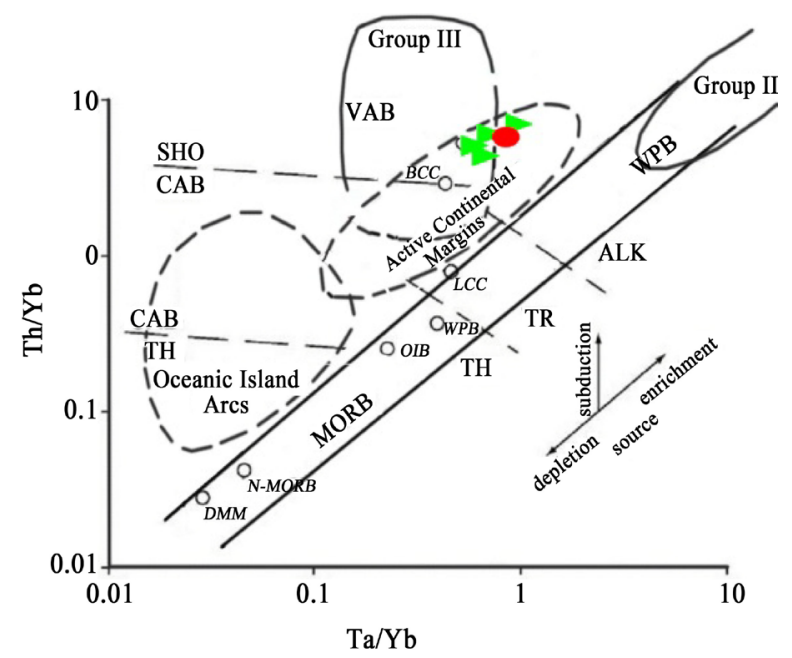

(b)

Figure 9. (a) Diagram Th/Yb-Ta/Yb provided by Pearce [10]. Samples are in the position of enriched mantle influenced by subduction makers. SHO: Shoshonitic; TH: Tholeiitic; TR: Transitional; ALK: Alkalin; (b) Diagram Nb/La-La/Yb taken from Aydin [13]. OIB average from Fitton [22], the lower crust from Chen [23], OIB and HIMU limits from Weaver [24]. Limit separator lines from Smith [12].

a result of low degree of partial melting of depleted peridotite origin in sub-continental lithospheric mantle influenced by subduction metasomatism (SCLM) [20] and [21].

Ghasemi Barghi [25] believes that in the north-west of Meshkin Shahr, the diversity of petrology, the number of eruptive phases and various forms of Eocene volcanic rocks are associated with volcanism. Due to high relative density of dikes (1.2\%), he believes that they are swarm dikes that are lava Eocene feeder and a sign of an extensional tectonic media. According to being after collision of these lavas and related dikes, he represents that, collision of irregular margins of continental convergent plates, causes collision crevasses [26]. Also he believes that, geometry and intensity of the collision was not so that the crevasse forms, but could have created multiple fractures perpendicular to the collision or reactivate old faults. Fractures which are deep are fed from deep sources of magma and alkaline magmas, and those which were associated with shallow nests, have reached evolved magmas to the surface. Also [27] in the site of continental collision in the north of Zagros-Belitis suture zone (Iran, Azerbaijan and Turkey) introduce two magmatic periods of Eocene and Miocene-Quaternary with composition of calc-alkaline—shoshonite and alkaline which have magmatism characteristics of the post-collision. They believe that increasing the amount of alkaline elements of the recent volcanic is caused by entering the asthenosphere magma during the final stages of post-collisional magmatism which due to partial melting and crustal contamination, they are associated with more differentiated types with calc-alkaline nature.

\section{Conclusion}

Dikes in the north of Saveh are swarm dikes with the nature of calc-alkaline and alkaline that a variety of calcalkaline types have more silica and lower relative age than alkaline types. Discontinuity of changes in main elements oxide in Harker diagrams in both dikes, although is not associated with increasing specific trends in the moving elements such as sodium and potassium, but genetic affinities that can be seen in the less-animated elements and dual nature with simultaneous presence of alkaline and calc-alkaline magmas, can be in an environment after collision and impact of AFC processes on penetrated primary magma in the crust lithosphere.

\section{References}

[1] Ernst, R.E., Buchan, K.L. and Palmer, H.C. (1995) Giant Dike Swarms, Characteristics, distrIbution and Geotectonic Applications. In: Baer, G. and Heimann, A., Eds., Physics and Chemistry of Dikes, Rotterdam, Balkema, 321.

[2] Hou, G.T. (2012) Mechanism for Three Types of Mafic Dyke Swarms. Geoscience Frontiers, 3, 217-223. http://dx.doi.org/10.1016/j.gsf.2011.10.003

[3] Hou, G.T., Kusky, T.M., Wang, C.C. and Wang, Y.X. (2010) Mechanics of the Giant Radiating Mackenzie Dyke 
Swarm: A Palaeostress Field Modeling. Journal of Geophysical Research, 115, 1-14. http://dx.doi.org/10.1029/2007JB005475

[4] Bazoobandi, M.H., Arian, M.A., Emami, M.H., Tajbakhsh, Gh.R. and Yazdi, S. (2015) Geodynamics of Dikes in North of Saveh. Open Journal of Ecology, 5, 452-459. http://dx.doi.org/10.4236/oje.2015.59037

[5] Ghalamghash, J. (1998) 1:100000 Scaled Map of Saveh. Geological Survey of Iran.

[6] Orang, K. (2014) Inversion Evidence of Sliding Vector in Kooshk-Nosrat Fault, North of Saveh. Journal of Earth Sciences, Geological Survey of Iran.

[7] Irvine, T.N. and Baragar, W.R.A. (1971) A Guide to the Chemical Classification of the Common Volcanic Rocks. Canadian Journal of Earth Sciences, 8, 523-548. http://dx.doi.org/10.1139/e71-055

[8] Cox, K.G., Bell, J.D. and Pankhurst, R.J. (1979) The Interpretation of Igneous Rocks. George Allen \& Unwin. http://dx.doi.org/10.1007/978-94-017-3373-1

[9] Sun, S.S. and McDonough, W.F. (1989) Chemical and Isotopic Systematics of Oceanic Basalts: Implications for Mantle Composition and Processes. In: Saunders, A.D. and Norry, M.J., Eds., Magmatism in Ocean Basins, Geological Society of London, Special Publication, 313-345. http://dx.doi.org/10.1144/GSL.SP.1989.042.01.19

[10] Pearce, J.A. (1982) Trace Element Characteristics of Lavas from Destructive Plate Boundaries. In: Thorpe, R.S., Ed., Andesites: Orogenic Andesites and Related Rocks, John Wiley and Sons, 252-548.

[11] Bradshaw, T.K. and Smith, E.I. (1994) Polygenetic Quaternary Volcanism at Crater Flat, Nevada. Journal of Volcanology and Geothermal Research, 63, 165-182. http://dx.doi.org/10.1016/0377-0273(94)90072-8

[12] Smith, E.I., Sánchez, A., Walker, J.D. and Wang, K. (1999) Geochemistry of Mafic Magmas in the Hurricane Volcanic Field, Utah: Implications for Small and Large Scale Chemical Variability of the Lithospheric Mantle. Journal of Geology, 107, 433-448. http://dx.doi.org/10.1086/314355

[13] Aydin, F., Karsli, O. and Chen, B. (2008) Petrogenesis of the Neogene Alkaline Volcanics with Implications for Post-Collisional Lithospheric Thinning of the Eastern Pontides, NE Turkey. Lithos, 104, 249-266. http://dx.doi.org/10.1016/j.lithos.2007.12.010

[14] Aldanmaz, E., Koprubas, N., Gurer, O.F., Kaymakc, N. and Gourgaud, V.A. (2006) Geochemical Constraints on the Cenozoic, OIB-Type Alkaline Volcanic Rocks of NW Turkey: Implications for Mantle Sources and Melting Processes. Lithos, 86, 50-76. http://dx.doi.org/10.1016/j.lithos.2005.04.003

[15] Aldanmaz, E., Yaliniz, M.K., Güctekin, A. and Goncüoglu, M.C. (2008) Geochemical Characteristics of Mafic Lavas from the Neotethyan Ophiolites in Western Turkey: Implications for Heterogeneous Source Contribution during Variable Stages of Ocean Crust Generation. Geological Magazine, 145, 37-54. http://dx.doi.org/10.1017/s0016756807003986

[16] El-Bialy, M.Z. (2009) On the Pan-African Transition of the Arabian-Nubian Shield from Compression to Extension: The Post-Collision Dokhan Volcanic Suite of Kid-Malhak Region, Sinai, Egypt. Gondwana Research, 17, 26-43. http://dx.doi.org/10.1016/j.gr.2009.06.004

[17] Liegeois, J.P., Navez, J., Hertogen, J. and Black, R. (1998) Contrasting Origin of Post-Collisional High-K Calc-Alkaline and Shoshonitic versus Alkaline and Peralkaline Granitoids. The Use of Sliding Normalization. Lithos, 45, 1-28. http://dx.doi.org/10.1016/S0024-4937(98)00023-1

[18] Bonin, B. (2004) Do Coeval Mafic and Felsic Magmas in Post-Collisional to Within-Plate Regimes Necessarily Imply Two Contrasting, Mantle and Crustal, Sources? A Review. Lithos, 78, 1-24. http://dx.doi.org/10.1016/j.lithos.2004.04.042

[19] Eyal, M., Litvinovsky, B., Jahn, B.M., Zanvilevich, A. and Katzir, Y. (2009) Origin and Evolution of Post-Collisional Magmatism: Coeval Neoproterozoic Calc-Alkaline and Alkaline Suites of the Sinai Peninsula. Chemical Geology, 269, 153-179. http://dx.doi.org/10.1016/j.chemgeo.2009.09.010

[20] Keskin, M., Pearce, J.A. and Mitchell, J.G. (1998) Volcano-Stratigraphy and Geochemistry of Collision-Related Volcanism on the Erzurum-Kars Plateau, North Eastern Turkey. Journal of Volcanology and Geothermal Research, 85, 355-404. http://dx.doi.org/10.1016/S0377-0273(98)00063-8

[21] Yilmaz, Y., Saroglu, F. and Guner, Y. (1987) Initiation of the Neomagmatism in East Anatolia. Tectonophyiscs, 134, 177-199. http://dx.doi.org/10.1016/0040-1951(87)90256-3

[22] Fitton, J.G., James, D. and Leeman, W.P. (1991). Basic Magmatism Associated with Late Cenozoic Extension in the Western United States: Compositional Variations in Space and Time. Journal of Geophysical Research, 96, 1369313712. http://dx.doi.org/10.1029/91JB00372

[23] Chen, W. and Arculus, R.J. (1995) Geochemical and Isotopic Characteristics of Lower Crustal Xenoliths, San Francisco Volcanic Field, Arizona, USA. Lithos, 110, 99-119. http://dx.doi.org/10.1016/0024-4937(95)00018-6

[24] Weaver, B.L., Wood, D.A., Tarney, J. and Joron, J. (1987) Geochemistry of Ocean Island Basalt from the South Atlan- 
tic: Ascension, Bouvet, St. Helena, Gough and Tristan da Cunda. In: Fitton, J.G. and Upton, B.G.J., Eds., Alkaline Igneous Rocks, The Geological Society, London, Special Publication, 253-267.

[25] Ghasemi Barghi, A. (2005) Petrology and Geochemistry of the Eocene Volcanic of Northwest of Meshkin Shahr. PhD Thesis, Shahid Beheshti University, Tehran, 336 p.

[26] Condie, K.C. and Crow, C. (1990) Early Precambrian Within-Plate Basalts from the Kaapvaal Craton in Southern Africa: A Case for Contaminated Komatiites. The Journal of Geology, 98, 100-107. http://dx.doi.org/10.1086/629378

[27] Dilek, Y., Imamverdiyev, N. and Altunkaynak, S. (2009) Geochemistry and Tectonics of Cenozoic Volcanism in the Lesser Caucasus (Azerbaijan) and the Peri-Arabian Region: Collision-Induced Mantle Dynamics and Its Magmatic Fingerprint. International Geology Review, 1-43. 